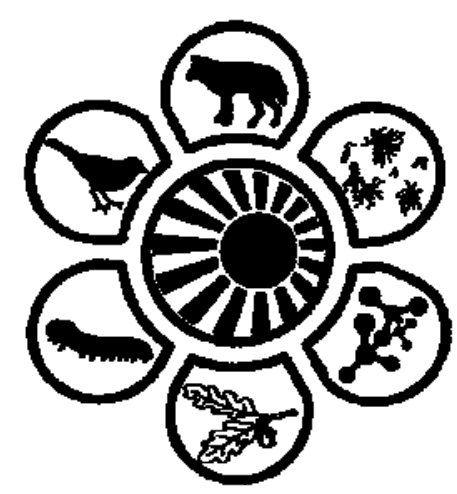

Вісник Дніпропетровського університету. Біологія, екологія.

Vìsnik Dnìpropetrovs'kogo unìversitetu. Seriâ Bìologiâ, ekologiâ

Visnyk of Dnipropetrovsk University. Biology, ecology.

Vìsn. Dnìpropetr. Unìv. Ser. Bìol. Ekol. 2016. 24(2), 258-263.

doi: $10.15421 / 011632$

ISSN 2310-0842 print

ISSN 2312-301X online

www.ecology.dp.ua

УДК 575.21+575.224

\title{
Characteristics of action of nitrosoalkylureas on cell level in winter wheat
}

\author{
M.M. Nazarenko \\ Dnipropetrovsk State Agrarian and Economic University, Dnipropetrovsk, Ukraine
}

\begin{abstract}
Here we report the cytogenetic characteristics of variability of mutation induction in new wheat varieties and some relationships between the means of the cytogenetic characteristics and different doses and types of mutagens. Analysis of chromosomal aberrations caused by mutagenic action of any kind of mutagen by the meto-anaphase method is one of the best known and most precise methods which we can use for determining the fact of mutagenic action on plants, and identifying the nature of the mutagenic factor. The strategy of investigation combined the identification of genotypes with a specific low-sensitivity to mutagenic factors using cytological analysis screening of mutagen treated wheat populations with the approach of comparing different varieties by breeding methods to reveal their connections and differences, specific sensitivity to mutagenic effects on the cell level. Dry seeds of 8 varieties of winter wheat were treated by nitrosomethilurea at concentrations $0.0125 \%, 0.0250 \%$, and nitrosoethilurea $0.010 \%, 0.025 \%$, which are normal levels for mutagenic selection of winter wheat mutation. The frequency and spectra of chromosomal aberrations were investigated. The overall correlations between the frequency of chromosomal aberrations and the value of a concentration were at the level $0.7-0.8$. It was established that the fragmentsbridges ratio is a reliable parameter for identifying the nature of mutagen. We identified genotypes and groups of genotypes which have a resistance to different types of mutagenic action. The resistance of a group is dependant on the breeding method of the variety initially obtained. It expressed as a decrease in the frequency of aberrations. Varieties obtained through chemical mutagenesis were less sensitive to the same chemical mutagens. Higher rates of chromosomal aberrations were typical for varieties obtained through field hybridization without any mutagen treatment or when the initial material was changed by low temperatures.
\end{abstract}

Keywords: chromosomal aberrations; mutagen; wheat; genotype

\section{Особенности воздействия нитрозоалкилмочевин на клеточном уровне у озимой пшеницы}

\author{
Н.Н. Назаренко
}

Днепропетровский государственный аграрно-экономический университет, Днепропетровск, Украина

Представлены результаты исследования по цитогенетическим характеристикам индуцированной мутационной изменчивости новых сортов пшеницы и некоторых связей между значением цитогенетических параметров и различными дозами и типами мутагенов. Анализ хромосомных аберраций, возникших в результате мутагенного воздействия любой природы, с помощью метоанафазного метода является одним из наиболее известных и точных методов, которые мы можем использовать для установления факта мутагенного воздействия на растение, идентификации мутагенного фактора. Комбинирование определения низкой чувствительности к мутагенному воздействию при использовании цитологического анализа для выявления мутагенного воздействия на обработанные сорта пшеницы со сравнением различных методов селекции сортов позволяет выявить их взаимосвязь и различия, специфику восприятия мутагенного действия на клеточном уровне. Сухие семена восьми сортов пшеницы озимой были обработаны нитрозометилмочевиной в концентрциях $0,0125 \%, 0,0250 \%$, нитрозоэтилмочевиной $-0,010 \%, 0,025 \%$. Данные концентрации являются обычными для мутационной селекции. Исследованы спектр и частота хромосомных аберраций. Общая корреляция между частотой хромосомных аберраций и концентрацией мутагена составляла $0,7-0,8$. Соотношение между мостами и фрагментами является надежным параметром идентификации природы мутагена. Мы классифицировали различные генотипы и группы генотипов по устойчивости к различным типам мутагенного воздействия. Устойчивость непосредственно зависела от метода получения исходного сорта. Она проявлялась в снижении частоты аберраций. Сорта, полученные с помощью химического мутагенеза, были

Днепропетровский государственный аграрно-экономический университет, ул. Ворошилова, 25, Днепропетровск, 49600, Украина Dnipropetrovsk State Agrarian and Economic University, Voroshilov Str., 25, Dnipropetrovsk, 49600, Ukraine

Tel.: +7095-848-53-86.E-mail:nik_nazarenko@ukr.net 
менее чувствительны к таким же мутагенам. Более высокие частоты хромосомных аберраций типичны для сортов, полученных методом полевой гибридизации без какого-либо мутагенного воздействия, или сортов, полученных при изменении исходного материала с помощью воздействия низких температур.

Ключевые слова: хромосомные аберрации; мутаген; пшеница; генотип

\section{Introduction}

Experimental mutagenesis studies the effects of any mutagen on living organisms. This includes radiation across the electromagnetic spectrum including X-rays, ultra-violet radiation, visible light, microwaves, radio waves, emissions due to radioactive decay, low-frequency radiation such as ultrasound, heat waves and related modalities, chemical and biological agents (Waugha, 2006). In radiobiology, most of the biological systems such as mammalian cells and bacteria generally are exposed to X-rays, $\gamma$-rays and electron beams for the investigation of the effects of radiation. High energy ion beams are utilized in some research (Lifang et al., 2001). In traditional radiobiology, most of the irradiated biological samples, such as cells or tissues, are in the atmosphere or even in the soil (Adlera et al., 2004).

Mutation has been described as a sudden change in the genetic material of living cells. However, at the beginning of mutation research, over 100 years ago, these sudden changes were observed and detected by the phenotypes they affected. The "sudden phenotypic changes" were heritable and therefore had a genetic base .Thus mutation detection and monitoring in research and plant breeding were based entirely on phenotyping. Later, from the mid-1950s onward, light microscopy provided a means of observing aberrations at the ploidy, karyotype and chromosome levels (Rank et al., 2002). Besides gene mutations, chromosomal aberrations in the form of deletions, inversions and translocations were produced (Shu et al., 2011). Translocations are most important for mutation breeding types of chromosome aberration, which may result from the rejoining of broken chromosomes. Irradiation tends to induce chromosome breaks, which can rejoin at random, resulting in translocations. These are likely to be deleterious. Ionizing radiation produces cytological aberrations and defects in chromosome segregation. Cytological aberrations observed in mitosis include the production of micro-nuclei and chromosomal abnormalities (Ukai, 2006; Shu et al., 2011).

Mutagenic effects of chemicals or ionizing radiation have been assessed by analysis of chromosomal aberrations (Rakhmatullina, 2007). Chromosomal abnormalities in irradiated mitotic cells range from breaks, through exchanges, laggards and anaphase bridges, dicentric and centric ring formations, terminal fragments with telomeric signal at only one end and interstitial fragments that appear as double minutes without any telomeric signals (Natarajan, 2005).

Mutated plants typically show reduced fertility, mainly caused by chromosomal rearrangements and genomic mutations during meiosis. For crops like wheat, individual tillers (side branches) originate from different cells of the embryo of the treated seeds. If an aberration occurs in one of these cells, it will be carried in the tiller developed from that cell (Hossain and Alam, 2001; Huaili et al., 2005; Shu et al., 2011).

Analysis of chromosomal aberrations after mutagenic action of any kind of mutagen by the meto-anaphase method is one of the most widespread and most precise methods which can be used for determining the fact of mutagenic action on plants, and identifying the nature of the mutagenic factor ( $\mathrm{Li}$ fang et al., 2001; Adlera et al., 2004; Ukai, 2006). Usually, analysis is widely used for establishing the fact, level and danger of environmental pollution by radionuclides (Korogodina et al., 1998), (Geraskin et al., 2002) and for determining optimal doses of radiation and chemical agents in work on plant breeding (Ahloowalia et al., 2004; Nazarenko, 2015). In the past 80 years, physical mutagens, mostly ionizing radiations, have been used widely for inducing hereditary aberrations and more than $70 \%$ of mutant varieties were developed using physical mutagenesis. However, this compound exhibits high mutagenic, clastogenic and recombinational activity in plants, frequently stronger than that of the most powerful alkylating agents (Grant and Owens, 2001). A correlation between "clastogenic adaptation" expressed as a reduction of chromatid type aberrations, micro-nuclei and aneuploid cells, and "clastogenic adaptation" has been shown (Bignold, 2005). Thus, we have the following reasons for the study of changes in chromosomes after mutagenic treatment: the determination of the suitability of a mutagen-polluted area for agriculture, correlation between aberrations and visible mutations in successive generations (for mutation breeding purposes) and for identifying the fact of mutagenic action and its nature.

The advantages of the method are promptness, objectivity of the results, the reliability and the ability to assess the impact of an integrated wide variety of mutagens by nature (van Harten, 1998; Karthika and Subba, 2006; Albokari, 2014).

Here we report on cytogenetic characteristics of variability of mutation induction in new wheat varieties and some relationships between the means of the cytogenetic characteristics and different doses and types of mutagens.

\section{Material and methods}

The following winter wheat varieties were treated by mutagens (in brackets are the method of obtaining varieties or the mutagens used) Favoritka, Lasunya, Hurtovina (irradiation of initial material by gamma rays), line 418, Kolos Mironovschiny (field hybridization), Sonechko (chemical mutagenesis, nitrosodimethilurea (NDMU) 0.005\%) and Kalinova (chemical mutagenesis, DAB 0.1\%), Voloshkova (thermomutagenesis - low plus temperature under vernalizaion was used as mutagen factor) in dry seeds-form. We used chemical mutagens: nitrosomethilurea (NMU) $0.0125 \%$ and $0.0250 \%$, nitrosoethilurea (NEU) $-0.010 \%$ and $0.025 \%$. Exposure to chemical mutagens lasted 18 hours. These concentrations and exposure are optimal for the breeding process, as has been repeatedly established earlier (Shu et al., 2011).

Cytological analysis was carried out by the standard method at temporary press-time preparations of root tips stained with acetocarmine. Tissue maceration was carried out at $45 \%$ solution of acetic acid (Natarajan, 2005; Rank et al., 2002). The seeds used in this study were of the $\mathrm{M}_{0}$ generation.

Mathematical processing of the results was performed by the method of analysis of variance, the variability of the mean 
difference was evaluated by Student's t-test, the grouping by the nature of mutagens was performed by cluster analysis (Euclidian distance) (Klekka, 1989). We used the standard tools of the program Statistica 8.0 for cluster analysis (Multivariate Exploratory Techniques, cluster analysis, single linkage, Euclidian distance), factor analysis (Statistics, ANOVA module).

\section{Results and discussion}

The results of our investigation are represented in Table 1 (total number of observations of mitosis, number of division cells with chromosomal aberrations, general frequency of aberrations). Frequencies were changed from $4.44 \%$ (Sonechko, NEU $0.01 \%$ ) to $22.69 \%$ (Voloshkova, NMU $0.025 \%$ ) of the total number of mitosis. All the variables are statistically significantly different from each other and from the control.

For unifying the scheme of statistical analysis, variables were grouped by type of mutagen and the significant difference calculated firstly from the control variant (soaking in water, without mutagen treatment) with the lowest dose of mutagen, and then the differences inside the group of variables. Frequency was statistically lower when we used chemical mutagens for the variety Sonechko obtained by NDMU. The same situation was observed in case of the variety Kalinova, when NMU and NEU were both used, but with a less significant decrease. Therefore, these two varieties are less sensitive to nitrosoalkylureas.

As we can see from Table 1, the highest frequency aberration in any cases was characteristic for varieties obtained by breeding without using any mutagens (line 418, Kolos Mironovschiny, Voloshkova). A higher frequency of aberrations was obtained by using NMS, then NEU. It is well known that NEU in comparable (by induction of visible mutations) concentrations induces chromosomal aberrations only at a low rate compared to other alkylureas (Shu et al., 2011). A high concentration of either mutagens was more effective for induction of chromosome aberrations. A high aberration rate was observed in Voloshkova. This variety was unstable in the control too.

Frequency $(x \pm S E)$ of chromosomal aberrations in $M_{1}$ generation of winter wheat varieties

Table 1

\begin{tabular}{|c|c|c|c|c|c|c|}
\hline \multirow{3}{*}{ Variant } & \multirow{2}{*}{$\begin{array}{l}\text { Mitosis, } \\
\text { number }\end{array}$} & \multicolumn{2}{|c|}{ Chromosomal aberrations } & \multirow{2}{*}{$\begin{array}{l}\text { Mitosis, } \\
\text { number }\end{array}$} & \multicolumn{2}{|c|}{ Chromosomal aberrations } \\
\hline & & number & $\%$ & & number & $\%$ \\
\hline & \multicolumn{3}{|c|}{ Favoritka } & \multicolumn{3}{|c|}{ Line 418} \\
\hline Control & 984 & 19 & $1.93 \pm 0.31$ & 962 & 11 & $1.14 \pm 0.11$ \\
\hline NMU, $0.0125 \%$ & 1048 & 139 & $13.26 \pm 1.29^{*}$ & 906 & 106 & $11.70 \pm 1.12^{*}$ \\
\hline NMU, $0.025 \%$ & 934 & 179 & $19.17 \pm 1.48^{*}$ & 983 & 188 & $19.12 \pm 1.57 *$ \\
\hline NEU, $0.010 \%$ & 1020 & 91 & $8.92 \pm 0.89^{*}$ & 1021 & 93 & $9.11 \pm 0.84^{*}$ \\
\hline \multirow[t]{2}{*}{ NEU, $0.025 \%$} & 940 & 141 & $15.00 \pm 1.39 *$ & 900 & 156 & $17.33 \pm 1.22^{*}$ \\
\hline & \multicolumn{3}{|c|}{ Lasunya } & \multicolumn{3}{|c|}{ Hurtovina } \\
\hline Control & 1056 & 15 & $1.42 \pm 0.19$ & 1034 & 12 & $1.16 \pm 0.11$ \\
\hline NMU, $0.0125 \%$ & 1019 & 121 & $11.89 \pm 1.28^{*}$ & 1005 & 143 & $14.22 \pm 1.37 *$ \\
\hline NMU, $0.025 \%$ & 844 & 161 & $19.09 \pm 1.43^{*}$ & 1022 & 223 & $21.83 \pm 1.59 *$ \\
\hline NEU, $0.010 \%$ & 1003 & 97 & $9.67 \pm 0.92 *$ & 1018 & 103 & $10.12 \pm 0.99 *$ \\
\hline \multirow[t]{2}{*}{\begin{tabular}{|l} 
NEU, $0.025 \%$ \\
\end{tabular}} & 1015 & 159 & $15.67 \pm 1.33^{*}$ & 1024 & 184 & $17.97 \pm 1.42 *$ \\
\hline & \multicolumn{3}{|c|}{ Sonechko } & \multicolumn{3}{|c|}{ Voloshkova } \\
\hline Control & 1026 & 8 & $0.78 \pm 0.04$ & 1003 & 31 & $3.09 \pm 0.34$ \\
\hline NMU, $0.0125 \%$ & 1027 & 56 & $5.45 \pm 0.34 *$ & 1002 & 142 & $14.17 \pm 1.17^{*}$ \\
\hline NMU, $0.025 \%$ & 981 & 108 & $11.01 \pm 0.99^{*}$ & 912 & 207 & $22.69 \pm 1.64^{*}$ \\
\hline NEU, $0.010 \%$ & 1013 & 45 & $4.44 \pm 0.44^{*}$ & 1005 & 116 & $11.54 \pm 1.02 *$ \\
\hline \multirow[t]{2}{*}{\begin{tabular}{|l|} 
NEU, $0.025 \%$ \\
\end{tabular}} & 972 & 97 & $9.98 \pm 0.98^{*}$ & 976 & 169 & $17.32 \pm 1.44^{*}$ \\
\hline & \multicolumn{3}{|c|}{ Kalinova } & \multicolumn{3}{|c|}{ Kolos Mironivschini } \\
\hline Control & 1047 & 9 & $0.86 \pm 0.11$ & 909 & 10 & $1.10 \pm 0.13$ \\
\hline NMU, $0.0125 \%$ & 1009 & 106 & $10.51 \pm 1.07^{*}$ & 1016 & 129 & $12.70 \pm 1.22 *$ \\
\hline NMU, $0.025 \%$ & 851 & 133 & $15.63 \pm 1.27^{*}$ & 917 & 190 & $20.72 \pm 1.61^{*}$ \\
\hline NEU, $0.010 \%$ & 984 & 78 & $7.93 \pm 0.64 *$ & 1014 & 89 & $8.78 \pm 0.82^{*}$ \\
\hline NEU, $0.025 \%$ & 846 & 135 & $12.96 \pm 1.33^{*}$ & 951 & 155 & $16.30 \pm 1.34^{*}$ \\
\hline
\end{tabular}

Note: $*$ - difference statistically significant at $\mathrm{t}_{0.01}$.

According to the results of cluster analysis (generated by number of chromosomal aberrations) (Fig. 1) a clear determining relationship was found between the method of obtaining the variety and the nature of the mutagenic factor. Four different groups of varieties were distinguished - by using gamma rays (Favoritka, Lasunya, Hurtovyna), by the action of chemical mutagens (Kalinova, Sonechko) and varieties obtained using recombinant breeding (Kolos Mironovschiny, line 418), and an entirely separate variety (Voloshkova) obtained through thermomutagenesis. Thus, this method of grouping finally confirmed the conclusion that the effect of a mutagenic factor is largely determined sensitivity to mutagenic action if these factors were used for obtaining the initial material. In general, when the concentration of mutagen increased, the frequency also increased. The proportion of complex aberrations also increased (Table 2). On the other hand, complex aberration (or double and more aberrations in one cell) occurs more frequently after NMU than NEU and in the latter case it is sometimes not manifested.

Analyzing the results of three-factor analysis ("genotype", "concentration" and "nature of mutagen") has shown that, the frequency of chromosome aberrations is affected primarily by the factor "dose", then "genotype", then the "nature of the mutagenic" factor. But the second and third 
factors characterized a larger part of the dispersion than the first. The identified effect of frequency decrease is due to genotype-mutagen nature interaction. Thus it is seen that reexposure to the same nature of the mutagen (for example, gamma-rays on the variety obtained by the action of this same mutagenic factor) leads to a significant decrease in the frequency of aberrations. The overall correlations between the frequency of chromosomal aberrations and the value of a concentration were at the level $0.7-0.8$.

\section{Spectra of chromosomal aberrations}

Table 2

\begin{tabular}{|c|c|c|c|c|c|c|c|c|c|}
\hline \multirow[t]{2}{*}{ Variant } & \multicolumn{2}{|c|}{$\begin{array}{c}\text { Fragments } \\
(\text { single }+ \text { double })\end{array}$} & \multicolumn{2}{|c|}{$\begin{array}{c}\text { Bridges (chromosome }+ \\
\text { chromatide) }\end{array}$} & \multirow{2}{*}{$\begin{array}{l}\text { Fragments / } \\
\text { bridges }\end{array}$} & \multicolumn{2}{|c|}{$\begin{array}{c}\text { Micronucleus, } \\
\text { lagging chromosome }\end{array}$} & \multicolumn{2}{|c|}{$\begin{array}{l}\text { Double and more aber- } \\
\text { rations per cell division }\end{array}$} \\
\hline & number & $\%$ & number & $\%$ & & number & $\%$ & number & $\%$ \\
\hline \multicolumn{10}{|c|}{ Variety Favoritka } \\
\hline Check & 6 & 54.55 & 5 & 45.45 & 1.20 & 0 & 0.00 & 2 & 18.18 \\
\hline NMU, $0.0125 \%$ & 81 & 58.27 & 50 & 35.97 & 1.62 & 8 & 5.76 & 6 & 4.32 \\
\hline NMU, $0.025 \%$ & 123 & 68.72 & 51 & 28.49 & 2.41 & 5 & 2.79 & 17 & 9.50 \\
\hline NEU, $0.010 \%$ & 51 & 56.04 & 40 & 43.96 & 1.28 & 0 & 0.00 & 4 & 4.40 \\
\hline NEU, $0.025 \%$ & 92 & 65.25 & 49 & 34.75 & 1.88 & 0 & 0.00 & 8 & 5.67 \\
\hline \multicolumn{10}{|c|}{ Variety Lasunya } \\
\hline Check & 4 & 26.67 & 11 & 73.33 & 0.36 & 0 & 0.00 & 0 & 0.00 \\
\hline NMU, $0.0125 \%$ & 76 & 62.81 & 40 & 33.06 & 1.90 & 5 & 4.13 & 11 & 9.09 \\
\hline NMU, $0.025 \%$ & 103 & 63.98 & 58 & 36.02 & 1.78 & 0 & 0.00 & 18 & 11.18 \\
\hline NEU, $0.010 \%$ & 56 & 57.73 & 39 & 40.21 & 1.44 & 2 & 2.06 & 6 & 6.19 \\
\hline NEU, $0.025 \%$ & 84 & 52.83 & 69 & 43.40 & 1.22 & 6 & 3.77 & 13 & 8.18 \\
\hline \multicolumn{10}{|c|}{ Variety Hurtovina } \\
\hline Check & 7 & 58.33 & 5 & 41.67 & 1.40 & 0 & 0.00 & 0 & 0.00 \\
\hline NMU, $0.0125 \%$ & 94 & 65.73 & 40 & 27.97 & 2.35 & 9 & 6.29 & 9 & 6.29 \\
\hline NMU, $0.025 \%$ & 171 & 76.68 & 39 & 17.49 & 4.38 & 13 & 5.83 & 25 & 11.21 \\
\hline NEU, $0.010 \%$ & 70 & 67.96 & 32 & 31.07 & 2.19 & 1 & 0.97 & 14 & 13.59 \\
\hline NEU, $0.025 \%$ & 106 & 57.61 & 71 & 38.59 & 1.49 & 7 & 3.80 & 18 & 9.78 \\
\hline \multicolumn{10}{|c|}{ Line 418} \\
\hline Check & 6 & 54.55 & 5 & 45.45 & 1.20 & 0 & 0.00 & 2 & 18.18 \\
\hline NMU, $0.0125 \%$ & 71 & 66.98 & 32 & 30.19 & 2.22 & 3 & 2.83 & 8 & 7.55 \\
\hline NMU, $0.025 \%$ & 122 & 64.89 & 56 & 29.79 & 2.18 & 10 & 5.32 & 24 & 12.77 \\
\hline NEU, $0.010 \%$ & 53 & 56.99 & 40 & 43.01 & 1.33 & 0 & 0.00 & 4 & 4.30 \\
\hline NEU, $0.025 \%$ & 87 & 55.77 & 54 & 34.62 & 1.61 & 15 & 9.62 & 26 & 16.67 \\
\hline \multicolumn{10}{|c|}{ Variety Kolos Mironovschiny } \\
\hline Check & 5 & 50.00 & 5 & 50.00 & 1.00 & 0 & 0.00 & 0 & 0.00 \\
\hline NMU, $0.0125 \%$ & 81 & 62.79 & 40 & 31.01 & 2.03 & 8 & 6.20 & 6 & 4.65 \\
\hline NMU, $0.025 \%$ & 116 & 61.05 & 70 & 36.84 & 1.66 & 4 & 2.11 & 18 & 9.47 \\
\hline NEU, $0.010 \%$ & 43 & 48.31 & 35 & 39.33 & 1.23 & 11 & 12.36 & 9 & 10.11 \\
\hline NEU, $0.025 \%$ & 82 & 52.90 & 59 & 38.06 & 1.39 & 14 & 9.03 & 17 & 10.97 \\
\hline \multicolumn{10}{|c|}{ Variety Sonechko } \\
\hline Check & 6 & 75.00 & 2 & 25.00 & 3.00 & 0 & 0.00 & 0 & 0.00 \\
\hline NMU, $0.0125 \%$ & 32 & 57.14 & 24 & 42.86 & 1.33 & 0 & 0.00 & 4 & 7.14 \\
\hline NMU, $0.025 \%$ & 51 & 47.22 & 46 & 42.59 & 1.11 & 11 & 10.19 & 4 & 3.70 \\
\hline NEU, $0.010 \%$ & 23 & 51.11 & 21 & 46.67 & 1.10 & 1 & 2.22 & 2 & 4.44 \\
\hline NEU, $0.025 \%$ & 51 & 52.58 & 34 & 35.05 & 1.50 & 12 & 12.37 & 21 & 21.65 \\
\hline \multicolumn{10}{|c|}{ Variety Kalinova } \\
\hline Check & 2 & 22.22 & 7 & 77.78 & 0.29 & 0 & 0.00 & 0 & 0.00 \\
\hline NMU, $0.0125 \%$ & 56 & 52.83 & 43 & 40.57 & 1.30 & 7 & 6.60 & 14 & 13.21 \\
\hline NMU, $0.025 \%$ & 64 & 48.12 & 59 & 44.36 & 1.08 & 10 & 7.52 & 22 & 16.54 \\
\hline NEU, $0.010 \%$ & 39 & 50.00 & 35 & 44.87 & 1.11 & 4 & 5.13 & 17 & 21.79 \\
\hline NEU, $0.025 \%$ & 63 & 46.67 & 61 & 45.19 & 1.03 & 11 & 8.15 & 23 & 17.04 \\
\hline \multicolumn{10}{|c|}{ Variety Voloshkova } \\
\hline Check & 16 & 51.61 & 13 & 41.94 & 1.23 & 2 & 6.45 & 5 & 16.13 \\
\hline NMU, $0.0125 \%$ & 101 & 71.63 & 39 & 27.66 & 2.59 & 1 & 0.71 & 11 & 7.80 \\
\hline NMU, $0.025 \%$ & 142 & 68.60 & 54 & 26.09 & 2.63 & 11 & 5.31 & 28 & 13.53 \\
\hline NEU, $0.010 \%$ & 78 & 67.24 & 38 & 32.76 & 2.05 & 0 & 0.00 & 16 & 13.79 \\
\hline NEU, $0.025 \%$ & 91 & 53.85 & 72 & 42.60 & 1.26 & 6 & 3.55 & 28 & 16.57 \\
\hline
\end{tabular}

After the spectra of chromosomal aberrations had been investigated, the following types were identified: chromosomal bridges and double-bridges, fragments of chromosomes and double-fragments, micronucleus, lagging chromosomes. Cases with two or more types of aberrations in one cell and fragments-bridges ratio were calculated separately (Table 2). After these data had been analyzed,we identified some correlations between mutagen concentrations and parameters of spectra. The quantity of any type of chromosomal aberrations increased with increase in the dose (correlation coeffi- 
cients $0.8-0.9$ ). In our past investigations gamma-rays induced more bridges than fragments (fragments-bridges ratio lower than 1) (Nazarenko, 2015). After chemical mutagens more fragments were observed (fragments-bridges ratio more than 1). As we can see, we will be able to use this pa- rameter to identify the nature of unknown mutagens if it is correct for other kinds of chemical mutagens. Both mutagens induced similar types of aberrations at a similar rate. The amount of any type of chromosome's changes increased with growth in the concentrations.

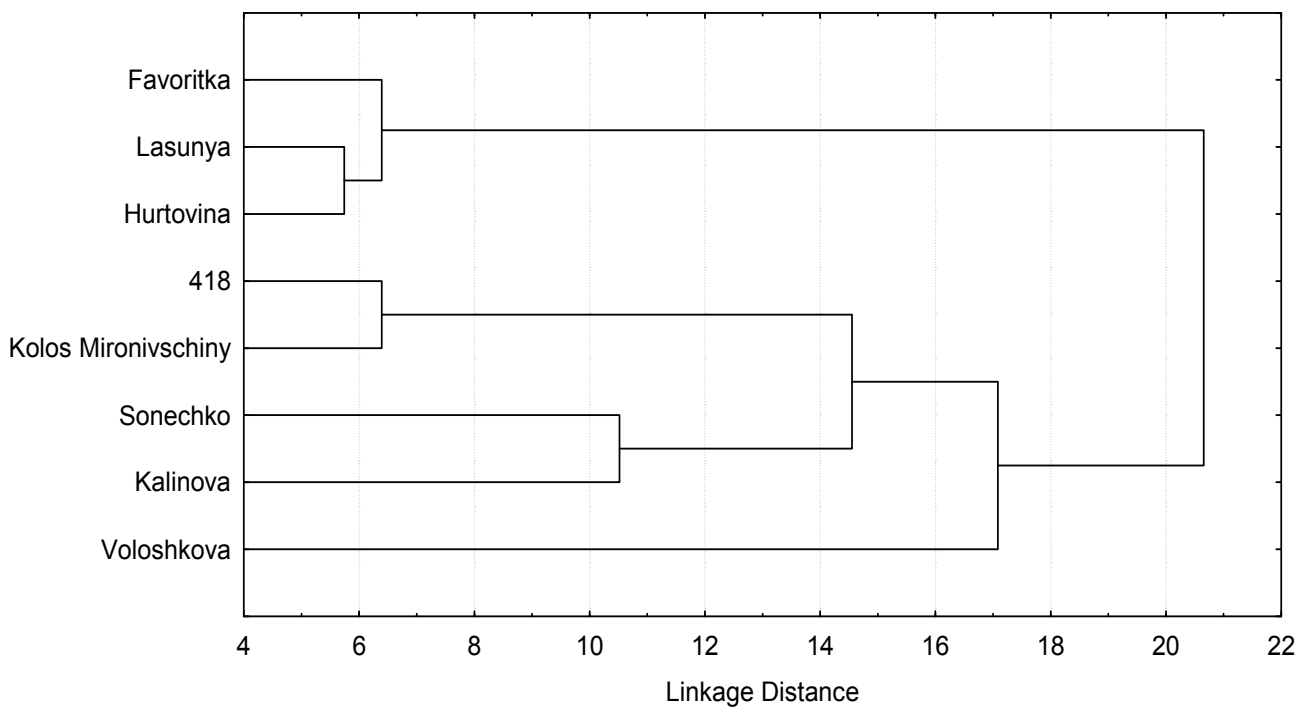

Fig. 1. The dendrogram was generated using the Euclidean distances, which shows the genetic diversity among 8 varieties

\section{Conclusions}

Chemically mutated varieties were less sensitive to the same chemical mutagens. As we can see, the varieties Sonecko and Kalinova are preferable for growth under this action. We can predict a smaller number of mutations when these varieties are used for mutation breeding purposes.

Higher rates of chromosomal aberrations are typical for varieties obtained by field hybridization without any mutagen treatment or when the initial material for breeding has been changed by low temperature action (variety Voloshkova).

Comparison of bridges and fragments is a reliable means of identification of the nature of a mutagen (chemical or gamma-rays). In the first case more fragments were induction, in the second - bridges.

In general, the frequency of any type of chromosomal aberration shows a linear increase with increase in concentrations of the mutagen.

\section{References}

Adlera, I., Carereb, A., Eichenlaub-Ritterc, U., 2004. Gender differences in the induction of chromosomal aberrations and gene mutations in rodent germ cells. Environmental Research 17, 53-59.

Ahloowalia, B.S., Maluszynski, M., Nicoterlein, K., 2004. Global impact of mutation-derived varieties. Euphytica 135, 187-204.

Albokari, M., 2014. Induction of mutants in durum wheat using gamma irradiation. Pak. J. Bot. 46, 317-324.

Bignold, L.P., 2009. Mechanisms of clastogen-induced chromosomal aberrations: A critical review and description of a model based on failures of tethering of DNA strand ends to strand-breaking enzymes. Mutat. Res. 681, 271-298.

Geraskin, A.S., Dikareva, V.G., Dikareva, N.S., 2002. Vliyanie razdelnogo radioaktivnogo i himicheskogo zagryazneniya na vyihod tsitogeneticheskih narusheniy $\mathrm{v}$ interkalyarnoy mer- isteme yarovogo yachmenya [Effect of separation of radioactive and chemical pollution output cytogenetic damage in intercalary meristem spring barley]. Radiation Biology Radioecology 42, 364-368 (in Russian).

Grant, W.F., Owens, E.T., 2001. Chromosome aberration assays in Pisum for the study of environmental mutagens. Mutat. Res. 488, 93-118.

Hossain, M.F., Alam, M.S., 2001. Effect of gamma irradiation on the callus, developed from indica rise. Pak. J. Biol. Sci. 6, 670-671.

Huaili, Q., Lanming, X., Fei, H., 2005. Biological effect of the seeds of Arabidopsis thaliana irradiated by $\mathrm{MeV}$ protons. Radiat. Eff. Defect. S. 160, 131-136.

Karthika, I.R., Subba, B., 2006. Effect of gama rays and EMS on two varieties of soybean. Asian Journal of Biological Sciences 5, 721-724.

Klekka, W.R., 1989. Diskriminantnyiy analiz. Faktornyiy, diskriminantnyiy, klasternyiy analiz [Discriminant analysis. Factorial, discriminant, cluster analysis]. Finansy, Moscow (in Russian).

Korogodina, V.L., Panteleeva, A., Ganicheva, I., 1998. Vliyanie moschnosti dozyi gamma-oblucheniya na mitoz i adaptivnyiy otvet kletok pervichnyih korney prorostkov goroha [Effect of gamma irradiation on mitosis and adaptive response of cells of the primary roots of pea seedlings]. Radiation Biology Radioecology 38, 643-649 (in Russian).

Lifang, W., Zengliang, Y., 2001. Radiobiological effects of a lowenergy ion beam on wheat. Radiat. Environ. Biophys. 40, 53-57.

Natarajan, A.T., 2005. Chromosome aberrations: Plants to human and feulgen to FISH. Curr. Sci. 89, 335-340.

Nazarenko, M., 2015. Negativnyie posledstviya mutagennogo vozdeystviya [Peculiarities of negative consequences of mutagen action]. Ecological Genetics 4, 25-26 (in Russian).

Nazarenko, M., 2015. Osobennosti vozdeystviya gamma-luchey na hromosomnyiy apparat kletki na primere pshenitsyi myagkoy ozimoy [The frequency and spectrum of chromosomal aberrations in root meristem cells of wheat under the action of mutagens]. Tambow State Unuversity Reports Natural and Technical Sciences 2, 449-452 (in Russian).

Rakhmatullina, E.M., Sanamyan, M.F., 2007. Estimation of efficiency of seed irradiation by thermal neutrons for induc- 
ing chromosomal aberration in M2 of cotton Gossypium hirsutum L. Russ. J. Genet. 43(5), 518-524.

Rank, J., Lopez, L.C., Nielsen, M.H., 2002. Genotoxicity of maleic hydrazide, acridine and DEHP in Allium cepa root cells performed by two different laboratories. Hereditas 136, 13-18.

Shu, Q.Y., Forster, B.P., Nakagawa, H. (ed.), 2011. Plant mutation breeding and biotechnology. FAO, Tokio.
Ukai, Y., 2006. Effectiveness and efficiency of mutagenic treatments: Gamma Field Symposia, 45, 1-4.

Van Harten, A.M., 1998. Mutation breeding. Theory and practical applications. Cambridge University Press, Cambridge.

Waugha, R., 2006. Harvesting the potential of induced biological diversity. Trends Plant Sci. 11, 71-79.

Надійила до редколегї 31.05.2016 